\title{
PELATIHAN PEMBUATAN KARYA SENI RUPA MELALUI TEKNIK KOLASE, MONTASE DAN MOZAIK PADA GURU DI SDN 67 KOTA BENGKULU
}

\section{TRAINING MAKING ART WORKS THROUGH COLLAGE, MONTAGE AND MOSAIK TECHNIQUES FOR TEACHERS IN SDN 67 KOTA BENGKULU}

\author{
Oleh: \\ Dwi Anggraini, Hasnawati, Pebrian Tarmizi \\ PGSD FKIP Universitas Bengkulu \\ dwianggraini@unib.ac.id, hasnaapril@gmail.com,
}

\begin{abstract}
This training is motivated by the needs of the 2013 curriculum for thematic teaching practices which contain subjects of SBDP in the field of fine arts at primary school level. This activity aims to improve the competence of classroom teachers both theoretically and practically in making of artwork using collage, montage and mosaic techniques. The method used is training and mentoring. Data collection techniques are observations to describe the process of collage, montage, and mosaic works and the implementation of collage, montage and mosaic learning in the classroom and tests to measure teacher knowledge (pretest and posttest). The results of this activity show that teachers can follow the process of training and practice, and the results of pretest and post-test show an increase only $17.65 \%$ of teachers who can get value of $\geq 60$ during the pretest, then increase to $73.53 \%$ of teachers are able to get value of $\geq 60$ at post-test. The conclusion is this activity can increase the knowledge of the target teacher in terms of both theoretical and practice.
\end{abstract}

Keywords: artwork, collage, mosaic, montage

\section{PENDAHULUAN}

Saat ini kebijakan kementrian pendidikan untuk jenjang sekolah dasar yaitu menerapkan Kurikulum 2013. SDN 67 Kota Bengkulu ini telah mulai menerapkan kurikulum 2013 dalam pembelajaran di kelas. Pendekatan pembelajaran yang digunakan ialah pendekatan pembelajaran tematik. Namun berdasarkan wawancara terhadap beberapa guru di sekolah tersebut terdapat beberapa masalah yang muncul dalam penerapan kurikulum 2013. Salah satu masalah yang muncul ialah dari mata pelajaran Seni Budaya dan Prakarya (SBdP).

Guru mata pelajaran SBdP di SDN 67 Kota Bengkulu ini tidak ada yang memiliki kualifikasi di bidang seni. Sehingga kemampuan dan keterampilan guru dalam mengajarkan mata pelajaran SBdP masih memprihatinkan. Guru tersebut cenderung mengajarkan mata pelajaran SBdP dengan menggambar dan menyanyi saja. Padahal berdasarkan kurikulum 2013 ruang lingkup mata pelajaran SBdP pada jenjang SD meliputi seni rupa, seni musik, seni tari, seni drama dan keterampilan. Salah satu masalah 
yang sering muncul ialah pada pembelajaran seni rupa. Kompetensi dasar (KD) seni rupa dalam SBdP salah satunya yaitu KD 4.4 Membuat karya kolase, montase, aplikasi, dan mozaik. Parahnya guru di sekolah tersebut masih belum paham dan belum terampil dalam membuat karya melalui teknik kolase, montase dan mozaik. Sehingga guru tidak bisa mengajarkan kompetensi dasar tersebut dengan baik. Dampaknya siswa menjadi tidak terampil dan tidak kreatif membuat karya dengan teknik tersebut. Hal tersebut menunjukkan bahwan tujuan pendidikan seni di SD masih belum berhasil.

Pendidikan seni rupa merupakan salah satu komponen dalam kurikulum SD yang berorientasi pada proses berpikir kreatif yang dapat mencerdaskan siswa. Selanjutnya tujuan dari pendidikan seni rupa di SD adalah untuk mengembangkan pengetahuan dan potensi siswa melalui kegiatan berkarya sesuai dengan tingkat perkembangannya (Muharam dan Warti, 1993). Fungsi utama dari adanya pendidikan seni rupa di SD yaitu untuk mengembangkan keterampilan berkarya dan menumbuhkembangkan rasa estetis dan apresiasi seni (Sumanto, 2011). Melalui seni rupa, Kamaril dkk (2006) menjelaskan bahwa siswa dapat mengekspresikan atau menuangkan ide pikiran maupun perasaannya kedalam bentuk karya yang menjadi cerminan keterampilan dan kreativitas yang dimilikinya.

Berdasarkan masalah yang dipaparkan di atas, dibutuhkan suatu pelatihan bagi guru SDN 67 Kota Bengkulu tentang bagaimana pengetahuan dan keterampilan dalam membuat karya melalui teknik kolase, montase dan mozaik. Pelatihan ini dirasakan sangat penting dan berharga bagi guru tersebut untuk memperbaiki kualitas proses dan hasil pembelajaran SBdP di sekolahnya. Untuk itu diharapkan pelatihan ini dapat dilaksanakan sesegera mungkin demi tercapainya siswa yang terampil, kreatif dan inovatif.

\section{METODE PENGABDIAN}

Kegiatan dilakukan selama dua tahap, yaitu tanggal 26 Agustus 2017 dan tanggal 2 September 2017 di SDN 67 Kota Bengkulu. Adapun yang menjadi sasaran dalam kegiatan ini adalah seluruh guru kelas SDN 67 Kota Bengkulu yang berjumlah 34 orang.

Metode yang digunakan yaitu pelatihan dan pendampingan. pelatihan dengan memberikan materi tentang teknik kolase, montase dan mozaik serta mempraktikkan teknik tersebut. Penyampaian materi mencakup teori tentang kolase, mozaik dan montase, jenis, bahan dan alat serta beberapa contoh karya kolase, mozaik dan montase. Selain itu materi yang disampaikan yaitu tentang unsur-unsur seni rupa dan prinsip-prinsip seni rupa yang harus diterapkan dalam membuat karya seni rupa dengan menggunakan teknik kolase, mozaik dan montase. Materi yang berkenaan dengan kolase, mozaik dan montase dikemas menjadi modul yang praktis untuk memudahkan guru apabila ingin mengulang kembali materi tersebut dilain waktu. Setelah mendapatkan materi, guru sasaran kemudian melaukan praktik membuat karya seni rupa dengan teknik kolase, montase dan mozaik. Selain pelatihan metode yang digunakan yaitu pendampingan. Kegiatan yang dilakukan dalam tahap ini yaitu praktik pembelajaran SBdP bidang Seni Rupa di kelas IV dengan menerapkan teknik kolase, montase dan mozaik. Tim PPM melakukan pendamping secara terus menerus untuk mengarahkan, membimbing, dan membantu guru sasaran dalam pendalaman materi kolase, montase DNA mozaik baik dari segi teoritis maupun praktis.

Teknik pengumpulan data yang digunakan adalah observasi dan tes. Observasi digunakan untuk mengamati proses kegiatan pelatihan dan praktik pembelajaran seni rupa di dalam kelas. Sedangkan tes untuk mengukur tingkat pengetahuan guru yang dilakukan sebanyak dua tahap, yaitu sebelum diberikan pelatihan (pre test) dan setelah pelatihan diberikan (pos test). 


\section{HASIL DAN PEMBAHASAN}

\section{Hasil}

\section{Hasil Observasi Proses Pembuatan Karya Kolase, Montase dan Mozaik}

Guru yang menjadi sasaran pengabdian dibagi menjadi 3 kelompok besar, yang mana masing-masing kelompok membuat karya seni rupa dengan menggunakan teknik yang berbeda-beda, sehingga hasil yang didapatkan juga berbeda-beda sesuai dengan teknik yang digunakan. Pengumpulkan data diawali dari proses pembuatan karya serta pengobservasian karya kolase, montase dan mozaik. Adapun hasil observasi yang diperoleh terdiri dari proses pembuatan karya montase dan karya montase adalah sebagai berikut.

\section{a. Deskripsi Pembuatan Karya Kolase}

Kelompok pertama membuat karya seni rupa menggunakan teknik kolase dengan tema hewan, yaitu burung merak. Langkah pertama yang dilakukan yaitu menyiapkan bahan-bahan. Adapun bahan yang telah disiapkan adalah karton bidang dasaran, sendok plastik, dakron, kertas origami yang berwarna-warni. Sedangkan alat dan bahan pembantu yang digunakan yaitu gunting, penggaris dan lem.

Langkah selanjutnya yaitu, guru membuat pola burung merak dengan menggunakan pensil. Kemudian menggunting kertas origami sesuai dengan bagian-bagian dari burung merak yang diinginkan. Untuk badan merak, dipilih warna pink dengan bintik-bintik biru. Warna merah dan kuning dipilih untuk membentuk sayap. Sedangkan untuk kepala dipilih warna biru dan menambahkan aksesoris pita di leher merak.

Selanjutnya untuk bagian ekor digunakan sendok plastik sebanyak 6 buah dengan posisi tertelungkup dan menambahkan guntingan kertas origami warna-warni pada bagian tangkai sendok. Pada bagian kaki juga digunakan sendok plastik. Hanya saja, untuk kaki yang digunakan hanya bagian tangkainya saja.

Karya kolase burung merak ini ditambah dengan guntingan kertas origami berwarna hijau yang dibentuk menyerupai rerumputan dan bunga-bunga, serta menggunakan dakron yang ditata di atas merak sebagai awan.

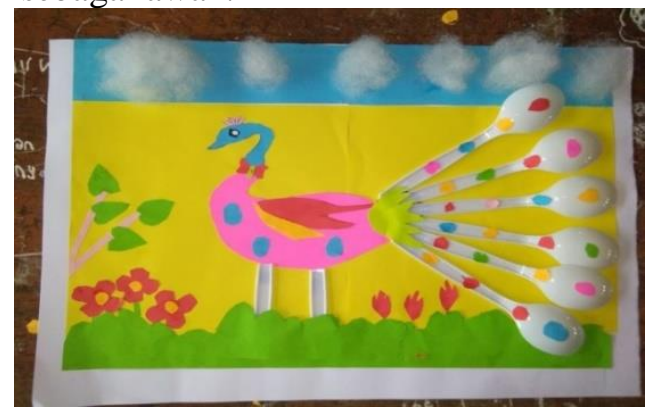

Gambar 1. Karya kolase "Burung Merak"

\section{b. Deskripsi Pembuatan Karya Montase}

Karya seni rupa dengan menggunakan teknik montase yang dibuat memilih tema alam/lingkungan. Langkah pertama yang dilakukan adalah persiapan dengan mengumpulkan bahan montase, bidang dasaran serta alat dan bahan pembantu. Bahan montase yang dikumpulkan berupa gambar-gambar. Adapun gambar-gambar yang berupa gambar-gambar yang berkaitan dengan lingkungan seperti gambar berbagai tumbuhan, hewan, dan manusia. Gambar-gambar tersebut didapatkan dari berbagai sumber, seperti majalah, kardus susu dan majalah. 
Selain bahan yang disiapkan adalah alat dan bahan pelengkap. Alat dan bahan pelengkap yang diperlukan adalah gunting, cat warna, penggaris, dan pensil serta karton sebagai bidang dasaran untuk membuat karya montase.

Langkah kedua yaitu menggunting gambar-gambar yang telah disiapkan tadi dan menyusun potongan gambar tersebut pada bidang dasaran dengan menggunakan lem kertas. Pada karya ini, selain potongan gambar, guru sasaran menggambarkan gunung dan jalan menggunakan pensil. Kemudian memberikan warna biru untuk gunung dan kuning untuk dasar karya secara keseluruhan.

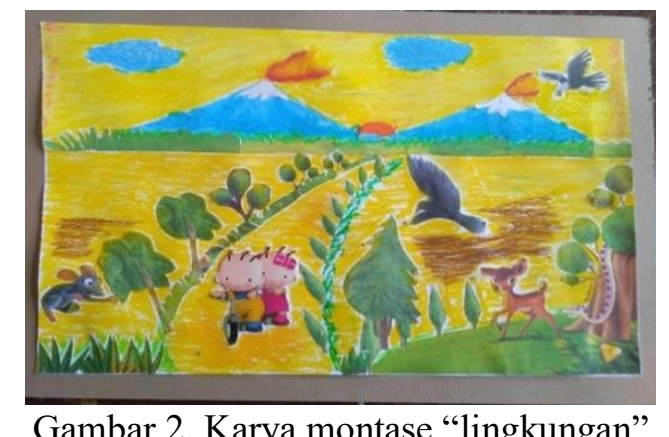

\section{c. Deskripsi Pembuatan Karya Mozaik}

Tema yang dipilih untuk membuat karya seni rupa dengan teknik mozaik yaitu hewan dalam hal ini hewan yang dilih adalah bebek. Langkah pertama yang dilakukan yaitu menyiapkan bahan dan alat. Bahan yang disiapkan adalah kertas origami warnawarni dan alatnya adalah gunting, lem, lidi, dan karton sebagai bidang dasaran.

Langkah selanjutnya, guru membuat pola bebek pada bidang dasaran. Kemudian menggunting kertas origami menjadi bagian-bagian kecil dan melemnya pada pola yang telah dibuat pada bidang dasaran sartu oersatu menggunakan lidi. Pertama kertas origami yang digunting berwarna krem yang digunakan untuk badan bebek. kemudian warna orange digunakan untuk memberi kesan belang pada bebek dan juga digunakan untuk mempertegas mulut bebek, serta untuk memberi warna pada gambar matahari dan batang pohon kelapa. Selanjutnya kertas yang digunting yaitu kertas origami warna biru untuk mewakili air sebagai tempat bebek itu berenang. Selain itu warna biru juga digunakan untuk memberi warna pada awan. Warna yang terakhir yaitu hijau yang digunakan untuk membentuk rumput dan daun pohon kelapa.

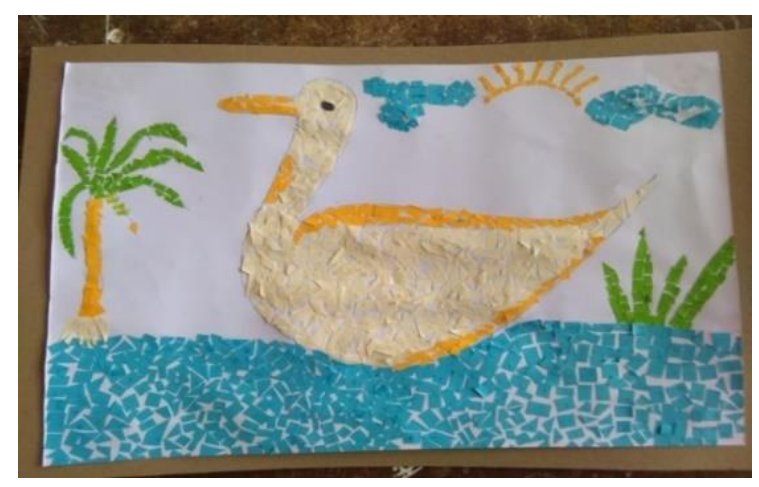

Gambar 3. Karya mozaik "Bebek" 


\section{Deskripsi Pelaksanaan Pembelajaran Seni Rupa}

Praktik pembelajaran seni rupa dilaksanakan pada tanggal 2 September 2017 di kelas IV SDN 67 Kota Bengkulu. Adapaun hasil pengamatan yang telah dilakukan adalah sebagai berikut.

\section{a. Kegiatan Pendahuluan}

Pada kegiatan pendahuluan guru membuka pembelajaran dengan salam dan mengecek kehadiran siswa. Setelah itu guru memberikan apersepsi yaitu menyanyikan lagu "mari menempel". Kemudian guru melakukan tanya jawab degan siswa tentang segala sesuatu yang berhubungan dengan menempel dan mengarahkannya dengan teknik menempel kolase, motase dan mozaik. Setelah itu guru menjelaskan tujuan pembelajaran dan menjelaskan tema menempel yang akan dilakukan.

\section{b. Kegiatan Inti}

Pada kegiatan inti, guru memperlihatkan beberapa contoh hasil karya dengan menggunakan teknik kolase, mozaik dan montase serta melakukan tanya jawab terkait materi tersebut. Kemudian siswa memperhatikan video pembuatan karya kolase, montase dan mozaik yang ditayangkan oleh guru sambil melakukan tanya jawab tentang proses pembuatan karya tersebut. Setelah melihat video, siswa dibagi menjadi tiga kelompok dengan rincian 1 kelompok membuat karya kolase, 1 kelompok membuat karya montase, dan 1 kelompok membuat karya mozaik. Kemudian guru membagikan LKS dan siswa membuat karya sesuai dengan prosedur yang terdapat pada LKS secara berkelompok.

Pada saat proses pembuatan karya, kelompok yang menemukan kesulitan yaitu kelompok mozaik. Kendala tersebut ada pada saat pengeleman. Siswa kesulitan melakukan pengeleman dikarenakan kertas yang dipotong-potong kecil-kecil. Sehingga lem diletakkan dibalik kertas kecil tersebut tidak rapih dan belepotan. Selain itu antusias anggota kelompok yang ingin turut berpartisipasi mengelem sangat tinggi. Jadi mereka terlihat saling berebutan sehingga hasil karyanya kurang rapih dan potongan kertas origami berserakan dibagian-bagian tubuh Doraemon. Pada karya kolase tampak siswa kurang maksimal memberikan warna dan memilih warna. Batas antara lautan dan daratan tidak terlihat jika tidak ada perbedaan warna dan juga mengaplikasikan unsur gelap terang. Hasil karya montase terlihat paling rapih dibandingkan dengan karya mozaik dan kolase. Karya yang dihasilkan tertata rapih dan sesuai dengan proporsinya. Terdapat juga unsur gelap terang yang merupakan bawaan dari potongan gambar yang dipilih sebagai bahan montase. Berikut ini hasil karya seni rupa siswa menggunakan teknik kolase, montase dan mozaik.

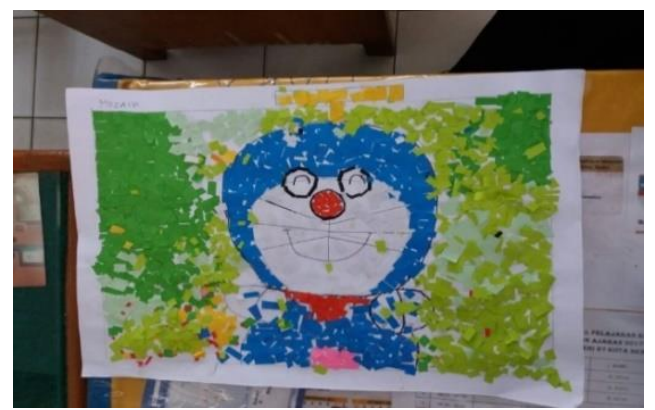

Gambar 4. Karya mozaik "Doraemon" 


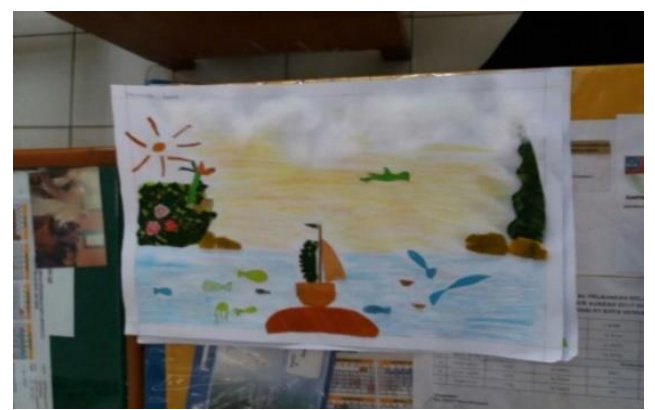

Gambar 5. Karya kolase "Hewan Laut"

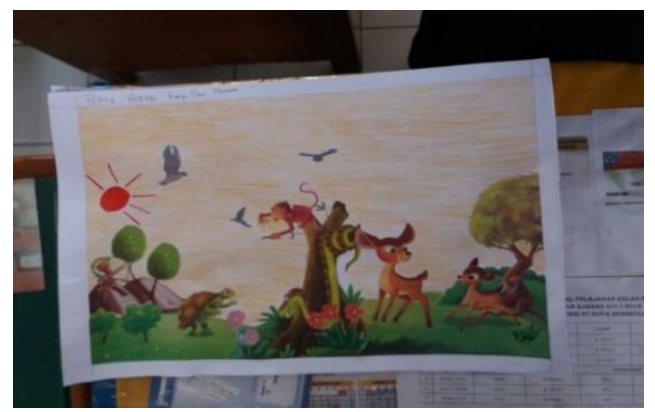

Gambar 6. Karya montase "Lingkungan"

Setelah siswa selesai membuat karya, siswa mempresentasikan hasil karyanya di depan kelas dan menjelaskan maksud dari karya yang telah dibut. Guru memberikan apresiasi dan masukan pada karya tersebut.

\section{c. Kegiatan Penutup}

Pada kegiatan penutup guru dan siswa menyimpulkan hasil pembelajaran yang telah dilakukan secara bersama-sama. Kemudian guru mengajak siswa berdo'a dan menutup pembelajaran.

\section{Tes}

Untuk mengukur pengetahuan guru sasaran tentang arya seni rupa dengan menggunakan teknik kolase, mozaik dan montase, dilakukan tes sebanyak dua tahap. Tahap petama tes dilakukan sebelum pelatihan dimulai (pre-test) dan tahap kedua dilakukan setelah pelatihan selesai dilaksanakan (pos-test). Berdasarkan pengolahan data, hasil tes dapat dirincikan pada tabel berikut ini.

Tabel 1. Persentase Hasil Pre-test Guru Sasaran

\begin{tabular}{llll}
\hline No & Kriteria & Jumlah Guru & Persentase \\
\hline 1 & $\geq 60$ & 6 & $17,65 \%$ \\
\hline 2 & $\leq 59$ & 28 & $82,35 \%$ \\
\hline
\end{tabular}

Berdasarkan pengolahan data persentase hasil pre-test tersebut, dapat terlihat bahwa sebagian besar guru sasaran belum memahami tentang karya seni rupa menggunakan teknik kolase, montase dan mozaik. Hal ini terlihat bahwa lebih dari $50 \%$ guru sasaran mendapatkan nilai $\leq 59$. Setelah mengikuti pelatihan dan mendapat penjelasan materi serta praktik membuat karya kolase, montase dan mozaik, guru diberikan pos test. Adapun hasil pos-test dapat dilihat pada tabel berikut ini. 
Tabel 2. Persentase Hasil Pos-test Guru Sasaran

\begin{tabular}{llll}
\hline No & Kriteria & Jumlah Guru & Persentase \\
\hline 1 & $\geq 60$ & 25 & $73,53 \%$ \\
\hline 2 & $\leq 59$ & 9 & $26,47 \%$ \\
\hline
\end{tabular}

Berdasarkan tabel di atas, dapat dilihat bahwa sebagian besar guru (lebih dari 50\%) mencapai nilai $\geq 60$, artinya guru sasaran sudah memahami tentang karya seni rupa dengan menggunakan teknik kolase, montase dan mozaik.

\section{Pembahasan}

\section{a. Proses Pembuatan Karya Kolase, Montase dan Mozaik}

Membuat karya seni rupa menggunakan teknik kolase, montase dan mozaik merupakan hal yang baru bagi guru-guru di SDN 67 Kota Bengkulu. Oleh sebab itu, semua guru tertarik dan merasa senang dengan adanya pelatihan ini, apalagi dengan adanya praktik membuat karya seni rupa kolase, montase, dan mozaik. Guru sasaran diberikan pretest sebelum pelatihan dimulai dan hasilnya menunjukkan lebih dari $50 \%$ guru belum memiliki pengetahuan tentang kolase, montase, dan mozaik. Hal ini dapat dirincikan sebagai berikut: (1) sebanyak 6 orang guru atau $17,65 \%$ mendapatkan nilai $\geq 60$, dan (2) sebanyak 28 orang guru atau $82,35 \%$ mendapatkan nilai $\leq 59$. Setelah diberikan pelatihan dengan materi kolase, montase dan mozaik terdapat perbedaan hasil yaitu lebih dari 50\% guru telah memiliki pengetahuan tentang kolase, montase dan mozaik dengan rincian sebagai berikut: (1) sebanyak 25 orang atau 73,53\% mendapatkan nilai $\geq 60$ dan (2) sebanyak 9 orang atau $26,47 \%$ mendapatkan nilai $\leq 59$. Dengan demikian pemahaman guru terhadap kolase, montase dan mozaik meningkat sebanyak 55,88 \%.

Setelah diberikan materi, guru sasaran kemudian praktik membuat karya yang dibagi menjadi dalam tiga kelompok. Yang pertama yaitu karya Kolase. Tema yang dipilih oleh guru sebagian besar melibatkan hewan. Seperti misalnya pada kelompok kolase membuat "Burung Merak". Tema yang dipilih merupakan hasil diskusi dan kesepakatan semua anggota kelompo.

Adapun bahan yang disiapkan yaitu sendok plastik, kertas origami dan dakron. Kertas origami digunting membentuk bagian-bagian tubuh burung merak, yaitu badan, sayap dan kepala. Selain itu kertas origami juga digunting membentuk rumput dan bunga. Sendok plastik ditata untuk menunjukkan bagian ekor merak. Sendok plastik ditata mengembang setengah lingkaran untuk memberikan kesan ekor burung merak yang mekar seperti merak yang sebenarnya. Selain bahan, yang dipersiapkan adalah alat. Alat yang dipersiapan yaitu gunting, bidang dasaran, penggaris dan lem.

Setelah menentukan tema, menyiapkan bahan dan alat, proses selanjutnya yaitu menggunting kertas origami sesuai dengan kebutuhan dan juga sendok serta dakron kemudian mengelemnya pada bidang dasaran yang telah dibuat sketsa terlebih dahulu sehingga menjadi suatu karya seni rupa yang utuh. Hal ini didukung oleh pendapat Sari (2014) bahwa kolase adalah pembuatan karya seni dua dimensi atau tiga dimensi dengan menggunakan material atau bahan dari kepingan yang sengaja dibuat dengan cara dipotong-potong dan disusun dengan menempelkan pada bidang datar dengan cara di lem.

Pada karya kolase yang dibuat menggunakan garis lengkung yang dominan dan beberapa garis lurus yang dibentuk oleh gagang sendok plastik. Garis lengkung yang dibentuk oleh potongan kertas membentuk badan merak, rumput, bunda dan mulut sendok memberikan kesan lembut dan mengakibatkan karya terlihat dinamis. Sedangkan garis lurus yang dibentuk oleh tangkai sendok plastik pada bagian ekor dan kaki memberikan kesan tegas. Hal ini sesuai dengan pendapat Aminuddin (2009), garis terdiri dari garis 
lurus (berkesan tegas dan keras), garis lengkung (berkesan lembut dan lentur), dan garis spiral atau pilin (berkesan luwes).

Warna yang dipilih dalam membuat karya kolase yaitu warna kuning, biru, merah. Warna-warna tersebut merupakan warna primer. Selain itu warna lainnya adalah pink dan hijau yang tergolong pada warna sekunder. Menurut Aminuddin (2009) warna primer terdiri dari kuning, merah dan biru. Sedangkan warna sekunder adalah perpaduan dari dua warna seperti hijau, ungu dan lain sebagainya.

Sama halnya dengan membuat karya kolase, tahap awal dalam membuat karya montase adalah menentukan tema, menyiapkan alat dan bahan. Bahan montase terdiri dari potongan-potongan gambar yang didapat dari berbagai sumber (majalah, koran, kardus susu, dan lain sebagainya. Alat yang digunakan yaitu gunting, lem, peggaris, pensil, pewarna dan juga bidang dasaran. Setelah itu menempelkan potongan-potongan gambar pada bidang dasaran. Hal ini sesuai dengan pendapat Muharrar dkk (2013) montase merupakan karya yang diciptakan dengan cara memotong objek gambar tertentu dari berbagai sumber yang ditempelkan pada bidang menjadi satu kesatuan yang utuh dan disesuaikan dengan tema. Sedangkan pedoman langkah-langkah pembuatan karya montase sesuai dengan pendapat Sumanto (2011) dimulai dengan persiapan yaitu: (1) mengumpulkan bahan montase berupa guntingan gambar atau photo dari berbagai sumber, (2) mempersiapkan bidang dasaran serta alat dan bahan pembantu yang digunakan. Selanjutnya lakukan langkah kerja: (1) penyusunan guntingan gambar atau penataan awal gambar atau photo sampai diperoleh komposisi yang bagus, (2) pengeleman atau penataan tetap dengan cara merekatkan guntingan gambar menggunakan lem, dan (3) pewarnaan dengan menambahkan goresan warna disekitar gambar/photo agar berkesan lebih indah.

Pada karya montase, terlihat unsur gelap terang yang ditampilkan pada gambar pohon dan hewan. Unsur gelap terang ini merupakan bawaan dari gambar yan digunting dari berbagai sumber tadi. Selain itu gelap terang juga tampak pada letusan gunung. Ungkapan gelap terang sebagai hubungan pencahayaan dan bayangan dinyatakan dinyatakan dengan gradasi mulai dari yang paling putih untuk menyatakan sangat terang dan yang paling hitam untuk menyatakan sangat gelap (Aminunddin, 2009).

Dalam membuat karya montase prinsip proporsi harus mendapat perhatian. Penempatan posisi ukuran potongan gambar harus ditata dengan tepat sehingga memberikan perbedaan kesan obyek yang jauh dan yang dekat maupun perbedaan ukuran tubuh hewan yang satu dengan yang lainnya (Kamaril, 2006). Dalam karya montase yang dibuat terdapat potongan gambar tikus pada bagian kiri bawah bidang dasaran. Ukuran tikus yang ditempelkan hampir sama dengan ukuran anak-anak yang sedang bermain sepeda dan kancil. Sehingga tikus ini terkesan tempelan saja dan tidak ada hubungannya dengan gambar lainnya.

Selanjutnya karya mozaik. Karya mozaik yang dibuat adalah karya yang bertemakan hewan. Langkah-langkah pembuatannya yang pertama yaitu menyiapkan alat dan bahan. Pada karya mozaik hanya menggunakan bahan yang sejenis namun berbeda warna. Adapun bahan yang disiapkan yaitu kertas origami warna-warni yang digunting menjadi bagian-bagian kecil. Sedangkan alat yang digunakan yaitu gunting, lem, lidi, dan juga bidang dasaran. Guntingan-guntingan kertas origami kemudian ditempelkan pada bidang dasaran yang terlebih dahulu telah dibuat sketsa yang sesuai dengan tema, yaitu "bebek". Seperti yang diungkapkan Sumanto (2006) bahwa mozaik merupakan gambar dengan pola tertentu dibuat dengan cara menempelkan bahan-bahan sejenis yang telah dipotong-potong menjadi bagian kecil dan disusun dengan cara dilem berdempetan dan teratur pada suatu bidang. 
Karya mozaik yang telah dibuat belum memenuhi kaidah mozaik yaitu berdempetan dan teratur. Potongan kertas origami ditempelkan tanpa mempertimbangkan garis yang diciptakan oleh potongan-potongan garis tersebut. Garis-garis tersebut harusnya saling bertemu dan menyatu. Cara menempelkannya kurang rapih dikarenakan komponennya yang kecil-kecil membuat guru sasaran kesulitan untuk menempelkannya.

\section{b. Pembelajaran Seni Rupa}

Proses pembelajaran yang telah dilakukan telah sesuai dengan RPP yang dirancang. Terkait dengan kolase, montase dan mozaik, guru telah menerapkan pembelajaran seni rupa ini cukup baik. Guru mengarahkan siswa pada kegiatan awal dengan memberikan apersepsi yaitu lagu "mari menempel" dan kemudian menyampaikan tujuan pembelajaran. Pada kegiatan inti guru memberikan beberapa contoh hasil karya kolase, montase dan mozaik serta video cara pembuatannya. Namun demikian siswa tidak terpengaruh dengan contoh-contoh yang ditayangkan, siswa tetap berkretaivitas dan menemukan idenya sendiri.

Siswa sangat antusias, karena hal ini merupakan hal yang baru dan menarik. Pada saat kerja kelompok, terlihat beberapa siswa yang tidak ikut terlibat dalam pembuatan karya. Hal ini dikarenakan jumah siswa dalam satu kelompok terlalu banyak, sehingga memberikan kesempatan kepada siswa-siswa yang malas untuk tidak bekerja sama dalam membuat karya.

Pada karya kolase yang dibuat siswa, pemilihan warna kurang menarik, sehingga tidak membantu memberikan kesan menonjol pada salah satu bagian. Sedangkan pada karya montase terlihat lebih menarik dan telah memikirkan prinsip proporsi. Siswa meletakkan burung yang jauh dari pandangan dengan ukuran yang kecil dibandingkan dengan burung yang dekat. Pada karya mozaik terlihat tidak rapih, potongan guntingan kertas berserakan pada bagian-bagian tubuh Doraemon.

Karya-karya yang dihasilkan oleh siswa cukup menarik dan kreatif. Anak usia SD merupakan masa emas berekspresi kreatif karena kadar kreativitas anak pada usia ini masih sangat tinggi. Anak dapat melakukan kegiatan berolah seni rupa secara wajar dan spontan karena daya nalar anak belum sampai membatasi keleluasaan anak dalam berkarya (Herawati dkk, 1999). Berbagai bahan dan teknik dapat diterapkan pada anak. Pengolahan bahan sederhana dari alam maupun limbah dapat menjadi media dalam mengembangkan kreativitas anak. Teknik dalam berkarya atau menghasilkan karya dua dimensi sangat memungkinkan anak berkreasi dan menemukan sendiri. Unsur kreativitas sangat penting bagi anak usia sekolah dasar karena selain membantu anak dalam mengembangkan kemampuan intelektual dan imajinasinya, kreativitas juga membantu pertumbuhan motorik atau gerak fisik anak.

\section{KESIMPULAN DAN SARAN}

\section{Kesimpulan}

Berdasarkan pelatihan dan pendampingan yang telah dilaksanakan, maka dapat disimpulkan sebagai berikut:

1. Guru SDN 67 telah memiliki pengetahuan tentang seni rupa.

2. Guru SDN 67 telah memiliki pengetahuan dan keterampilan dalam membuat karya kolase, montase, dan mozaik. 


\section{Saran}

Saran yang dapat diberikan untuk kegiatan pengabdian ini adalah:

1. Guru sebaiknya tidak membagi siswa dalam kelompok dengan jumlah yang besar.

2. Bahan yang dipilih untuk membuat karya kolase, montase dan mozaik sebaiknya yang mudah didapat.

3. Penggunaan gunting atau alat pemotong lainnya harus dalam pengawasan guru.

\section{DAFTAR PUSTAKA}

Aminuddin, 2009, Apresiasi dan Ekspresi Seni Rupa, Puri Pustaka, Bandung.

Herawati, Ida Siti, dan Iriaji, 1999, Pendidikan Seni Rupa, Departemen Pendidikan dan Kebudayaan Direktorat Jenderal Pendidikan Tinggi Proyek Pendidikan Guru Sekolah Dasar.

Kamaril, Cut, dkk., 2006, Pendidikan Seni Rupa/Kerajinan Tangan, Universitas Terbuka, Jakarta.

Muharam dan Warti Sundariyati, 1993, Pendidikan Kesenian II (Seni Rupa), Departemen Pendidikan dan Kebudayaan Direktorat Jenderal Pendidikan Tinggi Proyek Pembinaan Tenaga Kependidikan

Muharrar, Syakir, dan Sri Verayanti, 2013, Kreasi Kolase, Montase, Mozaik Sederhana, Erlangga, Jakarta.

Sari, Desi Ritna, 2014, Meningkatkan Kreativitas Seni Anak Melalui Teknik Kolase Dengan Media Serutan Pensil Pada Anak PAUD Tunas Bangsa Kelompok B Desa Merambung Kecamatan Ulu Manna Kabupaten Bengkulu Selatan, Laporan Penelitian, FKIP Universitas Bengkulu, Bengkulu.

Sumanto, 2006, Pengembangan Kreativitas Seni Rupa Anak Sekolah Dasar, Departemen Pendidikan Nasional Direktorat Jenderal Pendidikan Tinggi Direktorat Ketenagaan.

Sumanto, 2011, Pendidikan Seni Rupa di Sekolah Dasar, FKIP Universitas Negeri Malang, Malang. 